\title{
Synthesis and Evaluation of Antimicrobial Activity of New Imides and Schiff Bases Derived From Ethyl-4-Amino Benzoate
}

\author{
WUROOD S. AHMED', AMMAR A. RAZZAK MAHMOOD ${ }^{2 *}$ and REDHA I. AL-BAYATI ${ }^{3}$ \\ ${ }^{1}$ Department of Pharmacy, Al-Yarmouk University, Baghdad-Iraq. \\ ${ }^{2}$ Department of Pharmaceutical Chemistry, College of Pharmacy-University of Baghdad-Baghdad, \\ 10001, Iraq. \\ ${ }^{3}$ Department of Chemistry, College of Science, Al-Mustansirya University, Baghdad, 10001, Iraq. \\ ${ }^{*}$ Corresponding author E-mail: kubbaammar1963@gmail.com
}

http://dx.doi.org/10.13005/ojc/340533

(Received: August 06, 2018; Accepted: September 29, 2018)

\begin{abstract}
A series of disubstituted 1,3,4-oxadiazole derivatives, including: imides and Schiff bases, was achieved from the starting material, ethyl-4-aminobenzoate, which was converted to the corresponding 4-aminobenzohydrazide (1), by its reaction with hydrazine hydrate in absolute ethanol. Two oxadiazole parent nuclei had been synthesized from (1), the first nucleus 5-(4-aminophenyl)-1,3,4-oxadiazol-2amine(2), and the second is 5-(4-aminophenyl)-1,3,4-oxadiazole-2-thione (3). Compound (2) obtained from stirring methanolic solution of (1) with cyanogen bromide $(\mathrm{CNBr})$ and sodium bicarbonate $\left(\mathrm{NaHCO}_{3}\right)$ at RT. While compound (3) was synthesized by refluxing of (1) with $\mathrm{CS}_{2}$ in the presence of $(\mathrm{KOH})$, the produced potassium salt of hydrazide underwent cyclization by acidification with $10 \%$ $\mathrm{HCl}$. Meanwhile, the cyclic imides derivatives (4-6) and (10-12) were synthesized by thermal fusion of (2) or (3) with acid anhydrides, while Schiffs bases derivatives (7-9) and (13-15) were synthesized by a conventional method involved refluxing of (2) or (3) with different aromatic aldehydes, in acidic medium (using glacial acetic acid). The new derivatives had been tested against three Gram-positive bacteria (Staphylococcus aureus, Micrococcus luteus, and Bacillus pumilus) and two Gram-negative bacteria (Pseudomonas aeruginosa and Escherichia coll) and two fungal species: (Saccharomyces cerevisiae and Candida albicans). Among the synthesized derivatives, compound (15) displayed a moderate to potent antibacterial activity, against different (Gram - positive and Gram-negative) bacteria, and also showed a slight to moderate antifungal activity.
\end{abstract}

Keywords: Antimicrobial, Imides, Schiff base, Synthesis, 1,3,4-Oxadiazole derivatives.

INTRODUCTION

1,3,4-Oxadiazole is a heterocyclic fivemember ring possessing one oxygen atom and two nitrogen atoms. It is originated from a furan ring, where two methylene groups $(=\mathrm{CH})$ substituted with two pyridine type nitrogen atoms $(-\mathrm{N}=)^{1,2}$. The 1,3,4-oxadiazole nucleus and their 2,5-disubstituted 
derivatives have a significant pharmacological activity including, anti inflammatory $y^{3,4}$, anticancer ${ }^{5,6}$, antibacterial ${ }^{7}$, antifungal ${ }^{8}$, anti-HIV ${ }^{9}$ and antioxidant activities $^{10}$.

1,3,4-oxadiazole derivatives can go through different chemical reactions, which made them essential for new molecule preparation, due to their distinct chemical structure, that has vast pharmacological importance ${ }^{11}$.

Many methods in the literature document the synthesis of 1,3,4-oxadiazoles ${ }^{1,12,13}$. The more commonly used pathway for 1,3,4-oxadiazoles preparation, includes reactions of acid hydrazides with carboxylic acids/acid chlorides then after, cyclization or ring closure of diacylhydrazines via some of dehydrating agents, for example, phosphorous oxychloride ${ }^{14-18}$.

It has been documented that Gram-negative bacteria are much more resistant to different antimicrobial agents, as compared to Gram-positive bacteria ${ }^{19}$. The differences may be due to, the constituent of the cell wall in Gram-positive bacteria is of a simple and single layer, while the cell wall in Gram-negative bacteria possesses an "outer membrane" with high lipid and lipoprotein content, which is not found in Gram-positive bacteria ${ }^{20}$. Therefore the lipophilic nature of the cell membrane of Gram-negative bacteria is more resistant towards antibacterial agents, which functions as a strong barrier for a variety of antimicrobial agents. Therefore, compounds possessing hydrophilic properties, will not be able to penetrate the cell membranes of Gram-negative bacteria. Meanwhile, the cell wall of Gram- positive bacteria is not a complex structure like Gram- negative bacteria. Antibacterial agents can quickly collapse the bacterial cell wall of Gram-positive bacteria, which leads to disruption of the cytoplasm ${ }^{21}$.

This work targets to synthesize of new derivatives of cyclic imides and Schiff bases derived from two parent nuclei: 5-(4-aminophenyl)-1,3,4oxadiazol-2-amine (2), and 5-(4-aminophenyl)-1,3,4oxadiazole-2-thione(3), respectively. Imides are essential to lead components for natural products and drugs ${ }^{22}$. While, Schiff bases have been widely studied and the focus of different researches, due to their extensive use and distinct biological activities $^{23}$.

\section{MATERIALS AND METHODS}

The starting material for the synthesis of 1,3,4-oxadiazole derivatives, is ethyl-4-amino benzoate, and the first step of the reaction involves the formation of the corresponding hydrazide then after, preparation of two- parent nuclei (1) and(2).

All chemicals and solvents used during synthesis were of AR grade and used without further purification. Reaction monitoring was ascertained by thin-layer chromatography (TLC), using Silica gel $\mathrm{GF}_{254}$ (type 60) pre-coated Aluminium sheets, Merck (Germany) exposed to UV-254nm light, and the eluent used for TLC as follows: ethyl acetate: n-hexane 9:1 for compounds (1),(4) (5), (6), (8), (9), (11)and (12); ethyl acetate: n-hexane 9.5:0.5 for compound(2); ethyl acetate: n-hexane 6:4, for compounds (3), (10), (14) and (15); ethyl acetate: n-hexane 5:5, for compounds (7) and (13). All synthesized derivatives were characterized by spectroscopic analysis (FTIR and ${ }^{1} \mathrm{HNMR}$ ).

Melting points were measured using melting point apparatus in open capillary tubes, and are uncorrected. The IR spectra, were recorded, on( FTIR-600, UK) spectrophotometer, using (KBr disc), (u, $\left.\mathrm{cm}^{-1}\right)$.

Furthermore, ${ }^{1} \mathrm{HNMR}$ spectra were recorded on Bruker model Ultra shield $300 \mathrm{MHz}$, Avance II- at (Al-Bayt University-Jordan), using tetramethylsilane (TMS) as an internal standard, the chemical shift was expressed as ( $\delta=$ ppm), DMSO- ${ }_{\mathrm{d} 6}$ and acetone- ${ }_{\mathrm{d} 6}$ were used as solvents.

\section{Chemical Synthesis}

Chemical synthesis of all new derivatives is depicted in (scheme 1).

\section{Synthesis of 4-aminobenzohydrazide $(1)^{24}$}

Ethyl-4-aminobenzoate $(0.06 \mathrm{~mol}, 9.9$ g) was dissolved in $(30 \mathrm{~mL})$ of hydrazine hydrate $80 \%$, then absolute ethanol $(25 \mathrm{~mL})$ was added in a rounded bottom flask and refluxed for $8 \mathrm{~h}$. At the end of the reaction, as monitored by TLC, the mixture 
was cooled to room temperature (RT), the crystals formed, filtered and recrystallized from absolute $\mathrm{EtOH}$.

White crystals, yield $77 \%$, m.p. $222-225^{\circ} \mathrm{C}$, $\mathrm{IR}(\mathrm{KBr}),\left(\mathrm{v}, \mathrm{cm}^{-1}\right): 3271$ and 3234 prim. $\left(\mathrm{NH}_{2}\right)$ str, $3033 \operatorname{Ar}(\mathrm{CH})$ str, $1626(\mathrm{C}=\mathrm{O})$ amide str, 1604(NH) bend , $1545(\mathrm{C}=\mathrm{C})$ str, 843 out of plain (C-Hbenz.) bend.

Synthesis of 5-(4-aminophenyl)-1,3,4-oxadiazol2-amine (2) ${ }^{25}$

4-Aminobenzohydrazide(1), (0.013 mol, $2.0 \mathrm{~g})$ was dissolved in $(40 \mathrm{~mL})$ of $\mathrm{MeOH}$ with a solution of $\mathrm{NaHCO}_{3}(0.013 \mathrm{~mol}, 1.0 \mathrm{~g})$ in $(20 \mathrm{~mL})$ of distilled water, then addition of cyanogen bromide (CNBr), (0.013 mol,1.4 g), and stirring the mixture in a round flask overnight at $\mathrm{RT}$, then methanol is evaporated, $(30 \mathrm{~mL})$ of cold distilled water was added, the precipitate formed, obtained by filtration. Off-white to pink powder, yield $61 \%$, m.p $280-282^{\circ} \mathrm{C}$, $\mathrm{IR}(\mathrm{KBr}),\left(\mathrm{v}, \mathrm{cm}^{-1}\right): 3327$ \& 3224 prim $\left(\mathrm{NH}_{2}\right)$ str, $3060($ Ar-CH)str, $1608(\mathrm{C}=\mathrm{N})$ str, 1585,1570 \&1506 $(\mathrm{C}=\mathrm{C})$ str, 1290 asym (C-O-C) str, 1068 sym (C-O-C) str, 837 out of plain(C-Hbenz.)bend.; ${ }^{1} \mathrm{HNMR}(300$ $\left.\mathrm{MHz}, \mathrm{DMSO}_{\mathrm{d} 6}, \delta=\mathrm{ppm}\right):$ 7.40(s,2H, $\left.\mathrm{NH}_{2}\right) ; 6.85-6.50$ (m,4H, 4Ar-H); 5.60 (s,2H, $\mathrm{NH}_{2}$-oxadiaz).

\section{Synthesis of 5-(4-aminophenyl)-1,3,4-oxadiazole- 2-thione (3) $)^{24}$}

4-Aminobenzohydrazide (1) $(0.02 \mathrm{~mol}$, $3.0 \mathrm{~g})$ dissolved in absolute $\mathrm{EtOH}(20 \mathrm{~mL})$ and cooled to $20^{\circ} \mathrm{C}$ in the ice bath. Then after, addition of potassium hydroxide $(\mathrm{KOH})$ to the mixture, $(0.027$ $\mathrm{mol}, 1.5 \mathrm{~g})$ in an absolute $\mathrm{EtOH}(10 \mathrm{~mL})$, and stirred for $15 \mathrm{~min}$. Then $\mathrm{CS}_{2}(0.024 \mathrm{~mol}, 1.5 \mathrm{~mL})$ was added gradually. The reaction was refluxed for $12 \mathrm{~h}$, The solvent was reduced by rotary evaporator, and the produced solid was dissolved in $(25 \mathrm{~mL})$ of cold D.W and acidified with $10 \% \mathrm{HCl}$, until precipitation of light yellow crystals of (3) obtained and recrystallized from absolute $\mathrm{EtOH}$.

Light yellow crystals, yield $64 \%$, m.p 243-245 ${ }^{\circ} \mathrm{C}, \mathrm{IR}(\mathrm{KBr}),\left(\mathrm{v}, \mathrm{cm}^{-1}\right)$ : 3315 and 3220 prim $\left(\mathrm{NH}_{2}\right)$ str, $3059 \operatorname{Ar}(\mathrm{CH})$ str, 2557 str of $(\mathrm{SH})$ thiol gr,1618 (NH) bend, $1603 \mathrm{~cm}^{-1}(\mathrm{C}=\mathrm{N})$ str, 1570, 1512 and $1485(\mathrm{C}=\mathrm{C})$ str, 1271 asym (C-O-C) str, 1065 sym (C-O-C) str, 829 (out of plain C-Hbenz.) bend; ${ }^{1} \mathrm{HNMR}\left(300 \mathrm{MHz}, \mathrm{DMSO}_{\mathrm{d} 6}, \delta=\mathrm{ppm}\right): 7.48$ (d, 2H, 2Ar-H); 6.60(d, 2H, 2Ar-H); 5.90(brs, 1H,SH); 7.78(s,2H, $\left.\mathrm{NH}_{2}\right)$.

\section{General method for the synthesis of imide} derivatives (4-6)

In a pyrex test tube, added compound(2) $(0.0011 \mathrm{~mol}, 0.19 \mathrm{~g})$, and phthalic anhydride $(0.0022$ $\mathrm{mol}, 0.325 \mathrm{~g})$ or of maleic anhydride $(0.0022 \mathrm{~mol}$, $0.215 \mathrm{~g})$, or succinic anhydride $(0.0022 \mathrm{~mol}, 0.22 \mathrm{~g})$, mixed, and heated using oil bath $290^{\circ} \mathrm{C}$. The mixture stirred continuously by using pyrex glass road for $30 \mathrm{~min}$. then washed with diethyl ether and left to dry.

Synthesis2-((4-(5-(1,3-dioxoisoindolin-2-yl)1,3,4-oxadiazol-2-yl)phenyl)carbamoyl)benzoic acid (4)

Light yellow powder, yield 95\%, m.p 286$288^{\circ} \mathrm{C}, \mathrm{IR}(\mathrm{KBr}),\left(\mathrm{v}, \mathrm{cm}^{-1}\right): 3307(\mathrm{OH}$ of $\mathrm{COOH}) \mathrm{str}$, $3095 \operatorname{Ar}(\mathrm{CH})$ str, $1749(\mathrm{C}=\mathrm{O})$ acid str, 1685 and 1651 asym.\& sym. $(\mathrm{C}=\mathrm{O})$ amide str, $1604(\mathrm{C}=\mathrm{N}) \mathrm{str}, 1557$ $(\mathrm{C}=\mathrm{C})$ str, 1257 asym (C-O-C) str, 1043 sym (C-O-C) str, 835 out of plain (C-H benz.) bend; ${ }^{1} \mathrm{HNMR}(300$ $\left.\mathrm{MHz} \mathrm{DMSO}_{\mathrm{d} 6}, \delta=\mathrm{ppm}\right): 8.18-7.18(\mathrm{~m}, 12 \mathrm{H}, 12 \mathrm{Ar}-\mathrm{H})$; $10.60(\mathrm{~s}, 1 \mathrm{H}, \mathrm{OH})$.

Synthesis of 1-(4-(5-(2,5-dioxo-2,5-dihydro-1Hpyrrol-1-yl)-1,3,4-oxadiazol-2-yl)phenyl)-1Hpyrrole-2,5-dione (5)

Yellow powder; yield 92\%, m.p 244$246^{\circ} \mathrm{C}, \mathrm{IR}(\mathrm{KBr}),\left(\mathrm{v}, \mathrm{cm}^{-1}\right): 3012 \operatorname{Ar}(\mathrm{CH})$ str, 1664 $(\mathrm{C}=\mathrm{O})$ amide str, $1604(\mathrm{C}=\mathrm{N}) \mathrm{str}, 1552,1510$ and $1427(\mathrm{C}=\mathrm{C})$ str, 1238 asym (C-O-C) str, 845 out of plain (C-H benz.)bend; ${ }^{1} \mathrm{HNMR}\left(300 \mathrm{MHz}, \mathrm{DMSO}_{\mathrm{d} 6}\right.$, $\delta=p p m): 7.72(\mathrm{~m}, 4 \mathrm{H}, 4 \mathrm{Ar}-\mathrm{H}) ; 7.12(\mathrm{~d}, 2 \mathrm{H}$, maleimide $-2 \mathrm{H}) ; 6.36(\mathrm{~d}, 2 \mathrm{H}$, maleimide-2H); $10.55(\mathrm{~s}, 1 \mathrm{H}, \mathrm{OH}$ (keto/enol form).

Synthesis of 4-((5-(4-(2,5-dioxopyrrolidin1-yl)phenyl)-1,3,4-oxadiazol-2-yl)amino)-4oxobutanoic acid (6)

White powder, yield $89 \%$, m.p $252-254^{\circ} \mathrm{C}$, $\mathrm{IR}(\mathrm{KBr}),\left(\mathrm{v}, \mathrm{Cm}^{-1}\right): 3315(\mathrm{OH}) \mathrm{str}, 2935$ asym $\left(\mathrm{CH}_{2}\right), 1725$ $(\mathrm{C}=\mathrm{O})$ acid str, 1701 and 1666 ( $\mathrm{C}=\mathrm{O}$ amide) str, 1606 $(\mathrm{C}=\mathrm{N})$ str, 1583 and $1506(\mathrm{C}=\mathrm{C})$ str, 1061 sym (C-O-C) str, 835 out of plain (C-H benz.) bend; ${ }^{1} \mathrm{HNMR}(300 \mathrm{MHz}$, DMSO- $_{\mathrm{d},}, \delta=$ ppm: $12,10(\mathrm{~s}, 1 \mathrm{H}, \mathrm{OH}) ; 10.16(\mathrm{~s}, 1 \mathrm{H}, \mathrm{NH})$; 7.93-7.08 (m,4H,4Ar-H); 2.76(t,2H, $\left.\mathrm{CH}_{2}\right)$. Other $\mathrm{CH}_{2}$ \& $2 \mathrm{CH}_{2}$ groups of succinimide, were masked with $\mathrm{DMSO}_{\mathrm{d} 6}$ peak. 
Synthesis of (E)-4-(((4-(5-amino-1,3,4-oxadiazol-2yl)phenyl)imino)methyl)-2,6-dimethoxyphenol (7)

Glacial acetic acid ( $3 \mathrm{dr}$ ) was added to 3,5-dimethoxy-4-hydroxy benzaldehyde $(0.0036 \mathrm{~mol}$, $0.65 \mathrm{~g})$, dissolved in $(20 \mathrm{~mL})$ of $\mathrm{MeOH}$, the entire mixture stirred in a round bottom flask for $15 \mathrm{~min}$, then compound (2), $(0.0017 \mathrm{~mol}, 0.3 \mathrm{~g})$ in $(20 \mathrm{~mL})$ of $\mathrm{MeOH}$ was added, and refluxed for $5 \mathrm{~h}$. At the end of reaction, the mixture was cooled, then poured into a crushed ice to get a precipitate, which was collected by filtration, dried and washed with ethyl acetate, and recrystallized from $\mathrm{EtOH}$.

Yellow powder, yield $53 \%$, m.p $138-140^{\circ} \mathrm{C}$, $\mathrm{IR}(\mathrm{KBr}),\left(\mathrm{v}, \mathrm{cm}^{-1}\right): 3573(\mathrm{OH}) \mathrm{str}, 3361$ and 3329 $\left(\mathrm{NH}_{2}\right)$ str, 2941 and 2841 asym \& sym $(\mathrm{CH})$ str, 1606 and $1579(\mathrm{C}=\mathrm{N})$ str, 1512 and $1462(\mathrm{C}=\mathrm{C})$ str, 1252 (Ar-O- $\mathrm{CH}_{3}$ ) str, 1038 sym(C-O-C) str, 839 (out of plain $\mathrm{C}-\mathrm{H}$ benz.)bend; ${ }^{1} \mathrm{HNMR}\left(300 \mathrm{MHz}, \mathrm{DMSO}_{\mathrm{d} 6}, \delta=\mathrm{ppm}\right)$ : $9.77(\mathrm{~s}, 1 \mathrm{H}, \mathrm{OH}) ; 8.50(\mathrm{~s}, 1 \mathrm{H}, \mathrm{CH}=\mathrm{N}) ; 8.17-7.24(\mathrm{~m}$, $6 \mathrm{H}, 6 \mathrm{Ar}-\mathrm{H}) ; 7.80\left(\mathrm{~s}, 2 \mathrm{H}, \mathrm{NH}_{2}\right) ; 3.84\left(\mathrm{~s}, 6 \mathrm{H}, 2 \times \mathrm{OCH}_{3}\right)$.

Synthesis of (E)-5-(4-((4-methoxybenzylidene) amino)phenyl)-1,3,4-oxadiazol-2-amine (8)

Glacial acetic acid ( $3 \mathrm{dr}$ ) was added to 4-methoxy benzaldehyde $(0.0036 \mathrm{~mol}, 0.5 \mathrm{~g})$, the mixture stirred in a round bottom flask for $15 \mathrm{~min}$. then compound (2), $(0.0017 \mathrm{~mol}, 0.3 \mathrm{~g})$ in $(30 \mathrm{~mL})$ of $\mathrm{MeOH}$ was added, and refluxed for $6 \mathrm{~h}$. After completion of the reaction, the mixture was cooled to RT, and poured into crushed ice, to produce a precipitate, then filtered, dried and recrystallized from $\mathrm{EtOH}$.

Yellow powder, yield $55 \%$, m.p $254-256^{\circ} \mathrm{C}$, $\mathrm{IR}(\mathrm{KBr}),\left(\mathrm{v}, \mathrm{cm}^{-1}\right): 3303$ and 3240 prim $\left(\mathrm{NH}_{2}\right)$ str, 3120 ( $\mathrm{NH}$-tautomer) str, 2964 \& 2839 asym \& sym $(\mathrm{CH})$ of $\mathrm{CH}_{3}$ str, 1653 and $1597(\mathrm{C}=\mathrm{N})$ str, 1570 and $1510(\mathrm{C}=\mathrm{C})$ str, $1254\left(\mathrm{Ar}-\mathrm{O}-\mathrm{CH}_{3}\right)$ str, 845 (out of plain $\mathrm{C}-\mathrm{H}$ benz.) bend; ${ }^{1} \mathrm{HNMR}\left(300 \mathrm{MHz}, \mathrm{DMSO}_{\mathrm{d} 6}, \delta=\mathrm{ppm}\right.$ : 8.59(s, $1 \mathrm{H}, \mathrm{CH}=\mathrm{N}) ; 7.93-7.08\left(\mathrm{~m}, 8 \mathrm{H}, 8 \mathrm{Ar}-\mathrm{H}\right.$ and $\left.\mathrm{NH}_{2}\right)$; $3.85\left(\mathrm{~s}, 3 \mathrm{H}, 1 \mathrm{XOCH}_{3}\right)$.

Synthesis of (E)-5-(4-((4-nitrobenzylidene)amino) phenyl)-1,3,4-oxadiazol-2-amine (9)

Glacial acetic acid (3dr) was added to 4-nitrobenzaldehyde $(0.0036 \mathrm{~mol}, 0.54 \mathrm{~g})$ in $(10 \mathrm{~mL})$ of absolute EtOH. The entire mixture stirred in a round bottom flask for $15 \mathrm{~min}$, then compound (2), $(0.0017 \mathrm{~mol}, 0.3 \mathrm{~g})$ dissolved in $(20 \mathrm{~mL})$ of hot absolute $\mathrm{EtOH}$ was added, stirred and refluxed for $5 \mathrm{~h}$. The precipitate which is obtained, filtered and recrystallized from EtOH.

Yellow powder, yield $58 \%$, m.p $275-277^{\circ} \mathrm{C}$, $\mathrm{IR}(\mathrm{KBr}),\left(\mathrm{v}, \mathrm{cm}^{-1}\right): 3317$ and 3252 prim $\left(\mathrm{NH}_{2}\right)$ str, 3080 $\operatorname{Ar}(\mathrm{CH})$ str, $2898(\mathrm{CH})$ str, 1676 and $1597(\mathrm{C}=\mathrm{N})$ str, 1516 and1344 asym \&sym $\left(\mathrm{NO}_{2}\right)$ str, 865 out of plain (C-H benz.) bend; ${ }^{1} \mathrm{HNMR}\left(300 \mathrm{MHz}, \mathrm{DMSO}_{-\mathrm{d} 6}\right.$, $\delta=\mathrm{ppm}): 8.82(\mathrm{~s}, 1 \mathrm{H}, \mathrm{NH}) ; 8.42(\mathrm{~s}, 1 \mathrm{H}, \mathrm{CH}=\mathrm{N}) ; 8.24(\mathrm{~d}$, $2 \mathrm{H}, 2 \mathrm{Ar}-\mathrm{H}) ; 7.98(\mathrm{~d}, 2 \mathrm{H}, 2 \mathrm{Ar}-\mathrm{H}) ; 7.76(\mathrm{~d}, 2 \mathrm{H}, 2 \mathrm{Ar}-\mathrm{H})$; 7.28(d, 2H, 2Ar-H); 7.50(s,2H, $\left.\mathrm{NH}_{2}\right)$.

\section{General method for synthesis of imide derivatives (10-12)}

To a pyrex test tube added compound (3), $(0.001 \mathrm{~mol}, 0.19 \mathrm{~g})$ and phthalic anhydride $(0.001$ mol, $0.148 \mathrm{~g})$, or maleic anhydride $(0.001 \mathrm{~mol}, 0.1 \mathrm{~g})$, or succinic anhydride $(0.001 \mathrm{~mol}, 0.1 \mathrm{~g})$, mixed and heated using an oil bath $290^{\circ} \mathrm{C}$. The mixture stirred continuously by using pyrex glass road for $30 \mathrm{~min}$. then washed with diethyl ether and left to dry.

Synthesis of 2-(4-(5-thioxo-4,5-dihydro-1,3,4oxadiazol-2-yl)phenyl)isoindoline-1,3-dione (10)

Off-white powder, yield $89 \%$, m.p 289-

$291^{\circ} \mathrm{C}, \mathrm{IR}(\mathrm{KBr}),\left(\mathrm{v}, \mathrm{cm}^{-1}\right): 3225(\mathrm{NH}) \mathrm{str}, 3078$ $\operatorname{Ar}(\mathrm{CH})$ str, 1739 and 1712 asym \& sym $(\mathrm{C}=\mathrm{O})$ amide str, $1612(\mathrm{C}=\mathrm{N})$ str, 1514 and $1469(\mathrm{C}=\mathrm{C})$ str, 841 out of plain (C-H benz.) bend; ${ }^{1} \mathrm{HNMR}(300 \mathrm{MHz}$, DMSO- $\left._{\mathrm{d} 6}, \delta=\mathrm{ppm}\right):$ 8.06-7.69 $(\mathrm{m}, 8 \mathrm{H}, 8 \mathrm{Ar}-\mathrm{H})$.

Synthesis of 1-(4-(5-thioxo-4,5-dihydro-1,3,4oxadiazol-2-yl)phenyl)-1H-pyrrole-2,5-dione(11)

Dark yellow powder, yield 95\%, m.p 229-

$231^{\circ} \mathrm{C}, \mathrm{IR}(\mathrm{KBr}),\left(\mathrm{v}, \mathrm{cm}^{-1}\right): 3168(\mathrm{NH}) \mathrm{str}, 3030$ $\operatorname{Ar}(\mathrm{CH})$ str, $1687(\mathrm{C}=\mathrm{O})$ str, $1626(\mathrm{NH})$ bend, 1604 $(\mathrm{C}=\mathrm{N})$ str, $1514(\mathrm{C}=\mathrm{C}) \mathrm{str}, 847$ out of plain $(\mathrm{C}-\mathrm{H}$ benz.) bend; ${ }^{1} \mathrm{HNMR}\left(300 \mathrm{MHz}, \mathrm{DMSO}_{-}{ }_{\mathrm{d} 6}, \delta=\mathrm{ppm}\right)$ : 10.68(s,1H,NH); 7.87-7.81(m,4H,4Ar-H); $6.51(\mathrm{~d}, 1 \mathrm{H}$, maleimide-H); $6.33(\mathrm{~d}, 1 \mathrm{H}$,maleimide-H).

Synthesis of 4-oxo-4-((4-(5-thioxo-4,5-dihydro-1,3,4oxadiazol-2-yl)phenyl)amino)butanoic acid (12)

White powder, yield $85 \%$, m.p $233-235^{\circ} \mathrm{C}$,

$\mathrm{IR}(\mathrm{KBr}),\left(\mathrm{v}, \mathrm{cm}^{-1}\right): 3450(\mathrm{OH}) \mathrm{str}, 3323$ and 3126 $(\mathrm{NH})$ amide str, $3099 \operatorname{Ar}(\mathrm{CH})$ str, 2966 and 2890 asym \& sym $(\mathrm{CH})$ of $\mathrm{CH}_{2}$ str, $2652(\mathrm{SH})$ str, 1697 $(\mathrm{C}=\mathrm{O})$ of $\mathrm{COOHstr}, 1676(\mathrm{C}=\mathrm{O})$ amide str, 1608 $(\mathrm{C}=\mathrm{N}) \mathrm{str}, 1585,1516 \& 1493(\mathrm{C}=\mathrm{C}) \mathrm{str}, 847$ out of 
plain( C-H benz.) bend; ${ }^{1 H N M R(300 M H z, D M S O-~}$ d6, $\delta=\mathrm{ppm}): 14.60(\mathrm{~s}, 1 \mathrm{H}, \mathrm{OH}) ; 12.10(\mathrm{~s}, 1 \mathrm{H}, \mathrm{NH})$; 10.28(s, 1H,NH); 7.75(m,4H,4Ar-H); 3.24(t, 2H, $\left.\mathrm{CH}_{2}\right)$. Other $\left(\mathrm{CH}_{2}\right) \mathrm{gr}$, masked with DMSO- ${ }_{\mathrm{d} 6}$ peak.

Synthesis of (E)-5-(4-((4-hydroxy-3,5- dimethoxy benzylidene)amino)phenyl)-1,3,4-oxadiazole2(3H)-thione (13)

Glacial acetic acid $\left(3^{\text {dr }}\right)$ was added to 3,5-dimethoxy -4-hydroxy benzaldehyde (0.0017 mol, $0.3 \mathrm{~g}$ ) dissolved in absolute $\mathrm{EtOH}(20 \mathrm{~mL})$, the mixture stirred in a round bottom flask for $15 \mathrm{~min}$, then compound (3), $(0.0016 \mathrm{~mol}, 0.3 \mathrm{~g})$ dissolved in hot absolute $\mathrm{EtOH}(20 \mathrm{~mL})$, was added, and the mixture refluxed for $6 \mathrm{~h}$. After completion of reaction. It was cooled to RT, a precipitate formed, which was filtered and washed with ethyl acetate, then recrystallized from petroleum ether.

Orange powder, yield 62\%, m.p 258$260^{\circ} \mathrm{C}, \mathrm{IR}(\mathrm{KBr}),\left(\mathrm{v}, \mathrm{cm}^{-1}\right): 3519(\mathrm{OH}) \mathrm{str}, 3041$ $\operatorname{Ar}(\mathrm{CH})$ str, 2945 \& 2814 asym \& sym $(\mathrm{CH})$ of $\mathrm{CH}_{3}$ str, $2569(\mathrm{SH})$ str, 1651 and $1597(\mathrm{C}=\mathrm{N})$ str, 1512,1489 \& $1437(\mathrm{C}=\mathrm{C})$ str, 1234 asym $(\mathrm{C}-\mathrm{O}-\mathrm{C})$ str, 1097 sym(C-O-C) str, 862 (out of plain $\mathrm{CH}$ benz.) bend; ${ }^{1} \mathrm{HNMR}\left(300 \mathrm{MHz}, \mathrm{DMSO}{ }_{\mathrm{d} 6}, \delta=\mathrm{ppm}\right)$ : $9.73(\mathrm{~s}, 1 \mathrm{H}, \mathrm{OH}) ; 8.84(\mathrm{~s}, 1 \mathrm{H}, \mathrm{NH}) ; 8.45(\mathrm{~s}, 1 \mathrm{H}, \mathrm{CH}=\mathrm{N})$; 8.03-6.63(m,6H,6Ar-H); $\left(2 \times \mathrm{OCH}_{3}\right)$ masked behind $\mathrm{H}_{2} \mathrm{O}\left(\mathrm{DMSO}_{-\mathrm{d}}\right)$.

\section{Synthesis of (E)-5-(4-((4-methoxybenzylidene)} amino)phenyl)-1,3,4-oxadiazole-2(3H)-thione (14)

Glacial acetic acid (3dr) was added to 4-methoxybenzaldehyde $(0.0017 \mathrm{~mol}, 0.23 \mathrm{~g})$, the mixture stirred in a round bottom flask for $15 \mathrm{~min}$, then compound (3), $(0.0016 \mathrm{~mol}, 0.3 \mathrm{~g})$ dissolved in hot absolute $\mathrm{EtOH}(30 \mathrm{~mL})$, was added, and the mixture refluxed for $6 \mathrm{~h}$. At the end of reaction, it was cooled to RT, a precipitate formed which was filtered and recrystallized from petroleum ether.

Orange powder, yield 58\%, m.p 210$212^{\circ} \mathrm{C}, \mathrm{IR}(\mathrm{KBr}),\left(\mathrm{v}, \mathrm{cm}^{-1}\right): 3221(\mathrm{NH}) \mathrm{str}, 2931$ and 2835 asym \& sym $(\mathrm{CH})$ of $\mathrm{CH}_{3}$ str, 1610 $(\mathrm{C}=\mathrm{N})$ str,1514 and $1406(\mathrm{C}=\mathrm{C})$ str,1252 asym (C-O-C) str,1070 sym (C-O-C) str, $831 \mathrm{~cm}^{-1}$ (out of plain $\mathrm{CH}$ benz.)bend; ${ }^{1} \mathrm{HNMR}(300 \mathrm{MHz}, \mathrm{DMSO}-$ d6, $\delta=\mathrm{ppm}): 9.83(\mathrm{~s}, 1 \mathrm{H}, \mathrm{NH}) ; 8.54(\mathrm{~s} 1 \mathrm{H}, \mathrm{CH}=\mathrm{N}) ; 7.94-$ 6.53(m,8H,8Ar-H); $3.81\left(\mathrm{~s}, 3 \mathrm{H}, 1 \times \mathrm{OCH}_{3}\right)$.

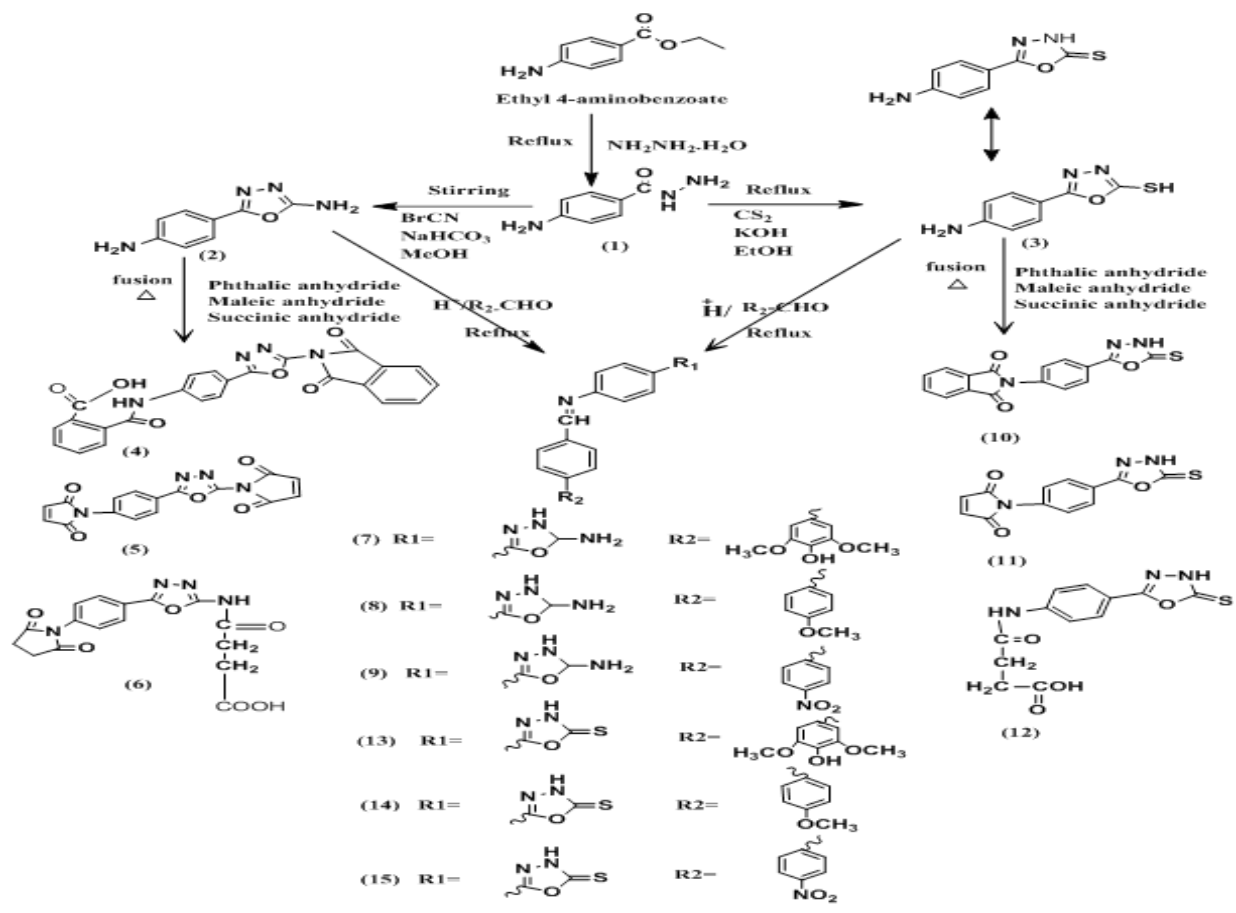

Scheme 1. Synthesis of titled compounds (1-15)

Synthesis of (E)-5-(4-((4-nitrobenzylidene)amino) phenyl)-1,3,4-oxadiazole-2(3H)-thione (15)

Glacial acetic acid( $\left(3^{d r}\right)$ was added to 4-nitrobenzaldehyde ( $0.0017 \mathrm{~mol}, 0.26 \mathrm{~g})$, the mixture stirred in a round bottom flask for $15 \mathrm{~min}$, then (3), $(0.0016 \mathrm{~mol}, 0.3 \mathrm{~g})$ dissolved in hot absolute $\mathrm{EtOH}(30 \mathrm{~mL})$, was added to the mixture, and refluxed for $6 \mathrm{~h}$. At the end of reaction, it was 
cooled to RT, the precipitate obtained, filtered, dried, washed with ethyl acetate, then recrystallized from $\mathrm{EtOH}$.

Orange powder, yield 55\%, m.p 258$260^{\circ} \mathrm{C}, \mathrm{IR}(\mathrm{KBr}),\left(\mathrm{v}, \mathrm{cm}^{-1}\right): 3070 \mathrm{~cm}^{-1} \operatorname{Ar}(\mathrm{CH}) \mathrm{str}$, 2920 and $2890 \mathrm{~cm}^{-1}$ asym \& sym aliphatic $(\mathrm{CH}) \mathrm{str}$, $1608 \mathrm{~cm}^{-1}(\mathrm{C}=\mathrm{N}) \mathrm{str}, 1589$ and $1489 \mathrm{~cm}^{-1}(\mathrm{C}=\mathrm{C}) \mathrm{str}$, 1516 and $1344 \mathrm{~cm}^{-1}$ asym \& sym( $\left(\mathrm{NO}_{2}\right)$ str, $858 \mathrm{~cm}^{-1}$ (out of plain $\mathrm{CH}$ benz.) bend; ${ }^{\mathrm{HNMR}}(300 \mathrm{MHz}$,DMSO$\left.{ }_{\mathrm{d} 6}, \delta=\mathrm{ppm}\right): 10.12(\mathrm{~s}, 1 \mathrm{H}, \mathrm{NH}) ; 8.84(\mathrm{~s}, 1 \mathrm{H}, \mathrm{CH}=\mathrm{N})$; 8.45-6.53(m, 8H,8Ar-H).

\section{Antibacterial Activity}

The new title compounds 4-15 were tested for their preliminary antibacterial activity and measured using well diffusion technique ${ }^{26}$ in vitro, against three types of tested microorganisms: Grampositive $\left(\mathrm{G}^{+\mathrm{ve}}\right)$ bacteria (S. aureus, Micrococcus luteus, and Bacillus pumilus), and two Gramnegative $\left(\mathrm{G}^{-\mathrm{ve}}\right)$ bacteria (Pseud. aeruginosa, and E. coli), were clinically activated and maintained on nutrient agar medium for testing antibacterial activity, and potato dextrose agar medium for antifungal activity ${ }^{27}$. Cefotaxime was used as a standard drug for antibacterial activity, while miconazole was used as a standard drug for antifungal activity, using a minimum inhibitory concentration, (MIC) of 1000 and $100 \mu \mathrm{g} / \mathrm{ml}$ of synthesized derivative in DMSO.

\section{RESULTS AND DISCUSSION}

\section{Chemistry}

The hydrazide (1) obtained by refluxing of the starting material ethyl-4-aminobenzoate with hydrazine hydrate in absolute ethanol. (1) characterized by FTIR, due to formation of two doublet peaks for the primary amine of hydrazide, at 3271 and $3234 \mathrm{~cm}^{-1}$, in addition, a prominent peak for the $(\mathrm{C}=\mathrm{O})$ amide stretching, at $1626 \mathrm{~cm}^{-1}$.

Two parent nuclei (2and 3 ), had been synthesized from (1), where (2) obtained from stirring a methanolic solution of (1) with cyanogen bromide $(\mathrm{CNBr})$, and sodium hydrogen carbonate, $\left(\mathrm{NaHCO}_{3}\right)$ at ambient temperature, while (3) obtained from refluxing an ethanolic suspension of (1) with $\mathrm{CS}_{2}$ in the presence of $\mathrm{KOH}$, the formation of potassium salt of hydrazide, which underwent cyclization by acidification with $10 \% \mathrm{HCl}$. Each parent nucleus
(2) and (3), displayed two peaks, at 3327 and $3224 \mathrm{~cm}^{-1}$ and 3315 and $3220 \mathrm{~cm}^{-1}$, respectively, that confirmed the presence of $\left(\mathrm{NH}_{2}\right)$ group. In addition, (3) recorded a peak at $2557 \mathrm{~cm}^{-1}$ due to thiol group (SH), and a peak at 1290 and $1271 \mathrm{~cm}^{-1}$ for (2) and (3), respectively, due to asym.(C-O-C) stretching, also, other peaks at 1068 and 1065 $\mathrm{cm}^{-1}$, respectively, owing to sym (C-O-C) stretching, (oxadiazole ring formation). The ${ }^{1} \mathrm{HNMR}$ spectrum for the parent nucleus (2) exhibited a singlet peak at $\delta=7.40 \mathrm{ppm}$, attributed to primary aromatic- $\mathrm{NH}_{2}$ group, as well as, a peak appeared at $\delta=5.60 \mathrm{ppm}$, due to $\left(\mathrm{NH}_{2}\right)$-oxadiazole.

The four aromatic protons of (2), displayed at $\delta=6.85-6.50 \mathrm{ppm}$, as a multiplet.

The second parent nucleus (3), displayed a peak at $\delta=7.78 \mathrm{ppm}$ corresponds to the presence of primary $-\mathrm{NH}_{2}$-group, while the four aromatic protons, for each (2) and (3), appeared at their expected region. See (exp. Part).

The cyclic imide derivatives (4-6) and (10-12), were synthesized in good yields, (85-95\%), by thermal fusion of (2) or (3), with one of the three acid anhydrides, phthalic, succinic and maleic.

The IR spectrum of (4), displayed a distinct band at $3307 \mathrm{~cm}^{-1}$ owing to $(\mathrm{OH})$ stretching of the carboxylic group. This indicate the opening of one imide ring, at one side of a ring fusion, besides that, a peak displayed at $1749 \mathrm{~cm}^{-1}$, due to $(\mathrm{C}=\mathrm{O})$ stretching of the carboxylic acid. Other peaks assigned for $(\mathrm{C}=\mathrm{O})$ amide stretching, at 1685 and $1651 \mathrm{~cm}^{-1}$, belong to the second fused imide ring. The ${ }^{1} \mathrm{HNMR}$ spectrum for (4) ), exhibited a prominent peak, at $\delta=10.60$ ppm, attributed to $(\mathrm{OH})$ signal of the carboxylic acid, this confirm the opening of one of phthalic imide ring , while the aromatic rings integrating for twelve protons, appeared at their expected aromatic region. (5) showed a prominent IR band at $1664 \mathrm{~cm}^{-1}$, due to conjugated $(\mathrm{C}=\mathrm{O})$ amide's stretching, and ' $\mathrm{HNMR}$ displayed two signals, each as a doublet, appeared at $\delta=7.12$ and $6.36 \mathrm{ppm}$, respectively, owing to the two protons of each maleimide ring.

The IR spectrum for (6) showed a characteristic carboxylic acid absorption, due to $(\mathrm{OH})$ stretching at $3315 \mathrm{~cm}^{-1}$, and a peak displayed at $1725 \mathrm{~cm}^{-1}$, assigned for $(\mathrm{C}=\mathrm{O})$ acid's stretching. 
Other peaks displayed at 1701 and $1666 \mathrm{~cm}^{-1}$ belong to $(C=O)$ stretching of amide, while ${ }^{1} \mathrm{HNMR}$ analysis for (6) is similar to (4), exhibited a peak at $\delta=12.10$, as a singlet, due to $(\mathrm{OH})$ signal of the carboxylic acid confirm the opening of one of succinimide ring), besides that, a peak integrating for two protons, belonging to $\left(\mathrm{CH}_{2}\right)$ group, displayed at $\delta=2.76 \mathrm{ppm}$, as a triplet. The second aliphatic $\left(\mathrm{CH}_{2}\right)$ group, and the two $\left(\mathrm{CH}_{2}\right)$ groups of succinimide ring, were masked with DMSO-d6 peak. (10) and (11) represent the product fusion, of each of phthalic anhydride, and maleic anhydride with (3), respectively, The $\mathrm{NH}$ stretching of thioamide, for each, (10) and (11), displayed at 3225 and $3168 \mathrm{~cm}^{-1}$ respectively, also IR spectra recorded two peaks assigned for the
$(\mathrm{C}=\mathrm{O})$ amide stretching, for (10) at 1739 and 1712 $\mathrm{cm}^{-1}$, while (11) displayed a $(\mathrm{C}=\mathrm{O})$ amide's stretching, at $1687 \mathrm{~cm}^{-1}$ due to (conjugation). The ${ }^{1} \mathrm{HNMR}$ of (10) showed peaks, as multiplet, at the range of $\delta=8.06$ $7.69 \mathrm{ppm}$, due to eight aromatic protons, While (11) showed a peak at $\delta=10.68 \mathrm{ppm}$, due to $\mathrm{NH}$-thioamide, also another two distinct signals, each attributed for one proton, appeared as a doublet, at $\delta=6.51$ and $\delta=6.33 p p m$, respectively, (maleimide ring).

The IR spectrum for (12) is similar to (6), in which succinimide ring is opened during thermal fusion. A recorded band at $3450 \mathrm{~cm}^{-1}$, assigned for $(\mathrm{OH})$ stretching of a carboxylic acid,(ring opening), a new peak at $1697 \mathrm{~cm}^{-1}$, due to $(C=O)$ of the

Table 1: The antibacterial activity of tested compounds (4-15)

Compd No. Conc. $\mu \mathrm{g} / \mathrm{ml}$ Staph. aureus Micrococcus luteus Bacillus pumilus Pseud. aeruginosa E.coli

Inhibition zone (mm)

\begin{tabular}{|c|c|c|c|c|c|c|}
\hline \multirow[t]{2}{*}{4} & $10^{3}$ & - & - & - & - & - \\
\hline & $10^{2}$ & - & - & - & - & - \\
\hline \multirow[t]{2}{*}{5} & $10^{3}$ & - & - & - & - & - \\
\hline & $10^{2}$ & - & - & - & - & - \\
\hline \multirow[t]{2}{*}{6} & $10^{3}$ & - & - & - & - & - \\
\hline & $10^{2}$ & - & - & - & - & - \\
\hline \multirow[t]{2}{*}{7} & $10^{3}$ & - & - & - & - & - \\
\hline & $10^{2}$ & - & - & - & - & - \\
\hline \multirow[t]{2}{*}{8} & $10^{3}$ & - & - & - & - & - \\
\hline & $10^{2}$ & - & - & - & - & - \\
\hline \multirow[t]{2}{*}{9} & $10^{3}$ & - & - & - & - & - \\
\hline & $10^{2}$ & - & - & - & - & - \\
\hline \multirow[t]{2}{*}{10} & $10^{3}$ & - & - & - & - & - \\
\hline & $10^{2}$ & - & - & - & - & - \\
\hline \multirow[t]{2}{*}{11} & $10^{3}$ & 8.3 & - & 8.1 & - & - \\
\hline & $10^{2}$ & - & - & - & - & - \\
\hline \multirow[t]{2}{*}{12} & $10^{3}$ & - & - & - & - & - \\
\hline & $10^{2}$ & - & - & - & - & - \\
\hline \multirow[t]{2}{*}{13} & $10^{3}$ & 10.6 & 10.5 & 11.5 & - & - \\
\hline & $10^{2}$ & - & - & - & - & - \\
\hline \multirow[t]{2}{*}{14} & $10^{3}$ & - & - & - & - & - \\
\hline & $10^{2}$ & - & - & - & - & - \\
\hline \multirow[t]{2}{*}{15} & $10^{3}$ & - & 22.7 & 11.6 & - & 14.1 \\
\hline & $10^{2}$ & _ & 18 & - & _- & - \\
\hline \multirow[t]{2}{*}{ Cefot. } & $10^{3}$ & 38 & 68 & 33 & 35.6 & 39 \\
\hline & $10^{2}$ & 31.8 & 63 & 25.8 & 30.8 & 32.12 \\
\hline DMSO & - & - & - & - & - & - \\
\hline
\end{tabular}


carboxylic acid stretching, While The ${ }^{1} \mathrm{HNMR}$ showed a signal for $(\mathrm{OH})$ of the carboxylic acid appeared at $\delta=14.60 \mathrm{ppm}$, in addition, two other signals, one displayed at $\delta=12.10$ and $10.28 \mathrm{ppm}$, attributed to $\mathrm{NH}$-thioamide and $\mathrm{NH}$-amide.

Schiff's bases (7-9) and (13-15) synthesized by a conventional method involved, refluxing of an ethanolic or methanolic solution of (2) or (3), with aromatic aldehydes in an acidic medium (using glacial acetic acid).

Table 2: The antifungal activity of tested compounds (4-15)

\begin{tabular}{cc}
$\begin{array}{c}\text { Compd } \\
\text { No. }\end{array}$ & $\begin{array}{c}\text { Conc. Saccharomyces } \\
\mu \mathrm{g} / \mathrm{ml}\end{array}$ \\
\hline cerevisiae & $\begin{array}{c}\text { Candida } \\
\text { albicans }\end{array}$ \\
\hline
\end{tabular}

\begin{tabular}{|c|c|c|c|}
\hline \multirow[t]{2}{*}{4} & $10^{3}$ & - & - \\
\hline & $10^{2}$ & - & - \\
\hline \multirow[t]{2}{*}{5} & $10^{3}$ & - & _- \\
\hline & $10^{2}$ & - & - \\
\hline \multirow[t]{2}{*}{6} & $10^{3}$ & - & _- \\
\hline & $10^{2}$ & - & - \\
\hline \multirow[t]{2}{*}{7} & $10^{3}$ & - & - \\
\hline & $10^{2}$ & - & - \\
\hline \multirow[t]{2}{*}{8} & $10^{3}$ & - & - \\
\hline & $10^{2}$ & - & - \\
\hline \multirow[t]{2}{*}{9} & $10^{3}$ & - & - \\
\hline & $10^{2}$ & - & - \\
\hline \multirow[t]{2}{*}{10} & $10^{3}$ & - & - \\
\hline & $10^{2}$ & - & - \\
\hline \multirow[t]{2}{*}{11} & $10^{3}$ & - & - \\
\hline & $10^{2}$ & - & - \\
\hline \multirow[t]{2}{*}{12} & $10^{3}$ & - & - \\
\hline & $10^{2}$ & - & - \\
\hline \multirow[t]{2}{*}{13} & $10^{3}$ & - & _- \\
\hline & $10^{2}$ & - & - \\
\hline \multirow[t]{2}{*}{14} & $10^{3}$ & - & - \\
\hline & $10^{2}$ & - & - \\
\hline \multirow[t]{2}{*}{15} & $10^{3}$ & 14.2 & 8 \\
\hline & $10^{2}$ & - & - \\
\hline \multirow[t]{2}{*}{ Miconazole } & $10^{3}$ & 15.8 & 32 \\
\hline & $10^{2}$ & 14 & 30.8 \\
\hline DMSO (control) & - & - & - \\
\hline
\end{tabular}

$(-)=$ No activity, slightly active $(Z \mathrm{I}=5-10 \mathrm{~mm})$, moderately active $(\mathrm{Zl}=10-15 \mathrm{~mm})$, highly active $(\mathrm{Zl}=$ more than $15 \mathrm{~mm}){ }^{28,29}, \mathrm{ZI}=$ Zone of inhibition
The characteristic imine group displayed in IR spectra at $1606,1579 \mathrm{~cm}^{-1}$ for (7), and at 1653 and $1597 \mathrm{~cm}^{-1}$ for (8), and at 1676 and $1597 \mathrm{~cm}^{-1}$ for (9), respectively. Also, (7) showed characteristic $(\mathrm{OH})$ stretching at $3573 \mathrm{~cm}^{-1}$ and $\left(\mathrm{Ar}-\mathrm{O}-\mathrm{CH}_{3}\right)$ absorption band, at $1252 \mathrm{~cm}^{-1}$, While for (8), a distinct peak for $\left(\mathrm{Ar}-\mathrm{O}-\mathrm{CH}_{3}\right)$ recorded at $1254 \mathrm{~cm}^{-1}$. Compound (9) exhibited a characteristic band, due to asym. $\left(\mathrm{NO}_{2}\right)$ stretching, at $1516 \mathrm{~cm}^{-1}$ and sym $\left(\mathrm{NO}_{2}\right)$ stretching at $1344 \mathrm{~cm}^{-1}$, on the other hand, Schiff bases, are well characterized by ${ }^{1} \mathrm{HNMR}$ spectroscopy, due to the appearance of imine group $(\mathrm{CH}=\mathrm{N})$, at $\delta=8.50,8.59$ and $8.42 \mathrm{ppm}$, for (7,8 and 9), respectively.

All the aromatic protons for (7-9) and (13-15), are well characterized and displayed at their expected aromatic regions. For more details, for the rest of the functional groups, see (exp. part).

\section{Antimicrobial Evaluation}

It's evident from the data displayed in Tables 1 and 2, compound (11) showed slight antibacterial activity against (Staph. aureus and Bacillus pumilus). Compound (13) showed moderate activity towards tested Gram positive bacteria. Among all synthesized compounds, (15) showed potent antibacterial activity against (Micrococcus luteus), moderate antibacterial activity against (Bacillus pumilus), moderate antibacterial activity against (E. coli), moderate antifungal activity against (Saccharomyces cerevisiae) and slight antifungal activity against (Candida albicans).

\section{CONCLUSION}

A new oxadiazoles derivatives (imides and Schiff bases), derived from ethyl -4-amino benzoate, were successfully synthesized, by thermal fusion , and conventional methods, respectively, they were characterized and evaluated for their antimicrobial activities.

Compound (11) showed a slight activity against some of Gram- positive bacteria, while (13) showed a moderate activity against all Gram-positive bacteria used in this evaluation. Furthermore, (15) displayed a moderate to potent antibacterial activity, against different (Gram-positive and Gram-negative) bacteria, and also showed a slight to moderate antifungal activity. 


\section{ACKNOWLEDGMENT}

We're grateful to the College of PharmacyDepartment of Pharmaceutical Chemistry-University of Baghdad, for conducting the research, and Dr. Raeid M. Al-Sayab/College Ibn -Al-Haitham, for Pure Science, for running ${ }^{1}$ HNMR analysis.

\section{REFERENCES}

1. Patel, Navin. B., Patel, Jaymin C., Synthesis and antimicrobial activity of 3-(1,3,4-oxadiazol2-yl)quinazolin-4(3H)-ones, Sci .Pharm., 2010, 78,171-193.

2. Panda, J.; Patro, V. J.; Panda, C. S.; Mishra J,and Mishra, J., Synthesis, characterization, antibacterial and analgesic evaluation of some 1,3,4-oxadiazole derivatives, Der Pharma Chemica., 2011, 3(2), 485- 490.

3. Nagalakshmi, G., Synthesis, antimicrobial and anti-inflammatory activity of-2,5-disubstituted1,3,4-oxadiazoles. Indian J Pharm Sci., 2008, 70 (1), 49-55.

4. Rajak, H.; Kharya, M. D.; and Mishra, P., Synthesis of some novel oxadiazole and oxadiazoline analogues for their antiinflammatory activity. Yakugaku Zasshil., 2007, 127 (10), 1757-1764.

5. Jin, L.; Chen, J.; Song, B.; Chen, Z.; Yang, S.; Li Q, Hu D; Xu, R., Synthesis, structure, and bioactivity of $\mathrm{N}^{\text {'-substituted }}$ benzylidene-3,4,5-trimethoxybenzohydrazide and 3-acetyl-2-substituted phenyl-5-(3,4,5trimethoxyphenyl)-2,3-dihydro-1,3,4oxadiazole derivatives. Bioorg Med Chem Lett., 2006, 16(19), 5036-5040.

6. Tuma, MC.; Malikzay, A.; Ouyang, X.; Surguladze, D.; Fleming, J.; Mitelman, S.; Camara, M.; Finnerty, B.; Doody, J.; Chekler, EL.; Kussie, P.; Tonra, J., Antitumor activity of IMC-038525, a novel oral tubulin polymerization inhibitor. Transl Oncol., 2010, 3(5), 318-325.

7. Banday, M. R.; Mattoo, R. H.; Rauf, A., Synthesis, characterization and antibacterial activity of 5-(alkenyl)-2-amino- and 2-(alkenyl)5-phenyl-1,3,4-oxadiazoles. J Chem Sci., Indian Academy of Sciences., 2010, 122 (2), 177-182.

8. Maslat, A. O.; Abussaud, M.; Tashtoush, H.; AL-Talib, M., Synthesis, antibacterial, antifungal and genotoxic activity of Bis-1,3,4oxadiazole derivatives, Pol J Pharmacol., 2002, 54, 55-59.
9. Shah, H. P.; Shah, B. R.; Bhatt, J. J.; Desai, N. C.; Trivedi, P. B.; Undavia, N. K., Synthesis of 2,5-disubstituted 1,3,4-oxadiazoles as potential antimicrobial, anticancer and antiHIV agents, Indian J Chem., 1998, 37(B), 180-182.

10. Maheshwari, R.; Chawla, P.; Saraf, S., Comparison between antioxidant activity of 2,5-disubstituted 1,3,4-oxadiazoles containing heteroaromatic ring and aromatic ring at $2^{\text {nd }}$ position, Med Chem Res., 2010, 3, 1-6.

11. Musmade, D. S.; Pattan, S. R.; and Manjunath, S. Yalgatti., Oxadiazole a nucleus with versatile biological behavior, Int J Pharm Chem., 2015, 5, 11-20.

12. Kerimov, I.; Ayhan-Kılcıgil, G.; Özdamar, E.D.; Can-Eke, B.; Çoban, T.; Özbey, S.; Kazak, C., Design and one-pot and microwaveassisted synthesis of 2-amino/5-aryl-1,3,4oxadiazoles bearing a benzimidazole moiety as antioxidants. Arch Pharm Chem Life Sci., 2012, 345, 349-356. [Google Scholar]

13. Katritzky, A.R.; Vvedensky, V.; Cai, X.; Rogovoy, B.; Steel, P.J. Synthesis of 5-(2arylazenyl)-1,2,4-triazoles and 2-amino-5aryl-1,3,4-oxadiazoles. ARKIVOC., 2002, 6, 82-90. [Google Scholar].

14. Kadi, AA.;El-Brollosy, NR.;Al-Deeb, OA.;Habib, EE.; Ibrahim, TM.; El-Emam, AA., Synthesis, antimicrobial, and anti-inflammatory activities of novel 2-(1-adamantyl)-5-substituted-1,3,4oxadiazoles and 2-(1-adamantylamino)-5substituted-1,3,4-thiadiazoles. Eur J Med Chem., 2007, 42(2),235-242. [PubMed].

15. Mickevicius, V.; Vaickelioniene, R.; Sapijanskaite, B., Synthesis of substituted 1,3,4-oxadiazole derivatives., Chem. Heterocycl Compd., 2009, 45(2),215-218.

16. Bentiss, F.; Lagrenee, M., A new synthesis of symmetrical 2,5-disubstituted 1,3,4oxadiazoles. J. Heterocycl. Chem., 1999, 36(4),1029-1032.

17. Liras, S; Allen, MP.; Segelstein, BE., A mild method for the preparation of $1,3,4$ - 
oxadiazoles: triflic anhydride promoted cyclization of diacylhydrazines. Synth Commun., 2000, 30(3),437-443.

18. Gomes, D.; Borges, CP.; Pinto, JC., Study of the synthesis of poly(4,4'-diphenyl ether-1,3,4oxadiazole) in solutions of poly(phosphoric acid) Polymer., 2001, 42(3),851-865.

19. Franski, R., Biological activities of the compounds bearing 1,3,4-oxa(thia)diazole ring. Asian $\mathrm{J}$ Chem., 2005, 17(4), 2063-2075.

20. A.P. Magiorakos; A. Srinivasan; R.B. Carey;Y. Carmeli; M.E. Falagas; C.G. Giske, Multidrugresistant, extensively drug-resistant and pan drug-resistant bacteria: an international expert proposal for interim standard definitions for acquired resistance. Clin Microbiol Infect., 2012, 18, 268-281.

21. Robert, D. Turner.; Alexander F. Hurd; Ashley Cadby; Jamie K. Hobbs; Simon J. Foster, Cell wall elongation mode in Gram-negative bacteria is determined by peptidoglycan architecture. Nat Commun., 2103, 4,1496

22. Nermina Malanovic; Karl Lohner, Grampositive bacterial cell envelopes: The impact on the activity of antimicrobial peptides. Biochimica et Biophysica Acta., 2016, 1858(5), 936-946

23. Nadjet, Rezki.; Amjad, M. Al-Yahyawi.; Sanaa, K. Bardaweel .; Fawzia, F. Al-Blewi.; and Mohamed, R. Aouad., Synthesis of novel 2,5-disubstituted-1,3,4-thiadiazoles clubbed 1,2,4-triazole, 1,3,4-thiadiazole, 1,3,4oxadiazole and/or Schiff base as potential antimicrobial and anti-proliferative agents, Molecules., 2015, 20,16048-16067.

24. Emad Ghanem; Sahar Al-Hariri; Abeer Ghanem; Lama Aouda, Synthesis, spectroscopic characterization, and powder XRD study of 4-(5-(ethylthio)-1,3,4oxadiazole-2-yl) aniline. Am J App Chem., 2105, 3(5-1), 1-6

25. Henryk, Foks.; Mieczyslaw, Janowiec.; Zofia, Zwolska.; and Ewa, AugustynowiczKopec., Synthesis and tuberculostatic activity of some (4-phenylpiperazin-1-ylmethyl)1,3,4-oxadiazole and (4-phenylpiperazin-1ylmethyl)-1,2,4-triazole derivatives. Acta Pol Pharm., 2004, 61(6), 473-476 .

26. Mounyr Balouiri; Moulay Sadiki; Saad Koraichi Ibnsouda; Methods for in vitro evaluating antimicrobial activity: A review. J. Pharm. Anal., 2016, 6(2), 71-79.

27. Antara Sen; Amla Batra; Evaluation of antimicrobial activity of different solvent extracts of medicinal plants: Melia azderach, 2012, 4(2), 67-73

28. Dabholkar,VV.; and Gavande, RP., Synthesis and antimicrobial activities of novel 1 , 4-benzothiazine derivatives. Arabian J. Chem., 2016, 9, 225-S229.

29. Ali, PS.; Meshram, JS.; and Raut RD., Theoretical and synthetic approach towards the biology of some novel monobactam induced sulphonamides: assessing biology through coupling of active ingredients. Jordan J. Chem., 2011, 6(1), 153-164. 